\title{
S. A. R. A. - den ideelle legebil?
}

Norges første motorvognregister ble påbegynt i 1899 av Oslo politistasjon, og Vegvesenet begynte å føre register fra 1912. En av yrkesgruppene som virkelig hadde nytte av at bilene etter hvert begynte å rulle ut på norske veier, var legestanden. Bilen ble et uvurderlig verktøy i et land med store avstander. Men hva var egentlig den ideelle legebilen? Flere kandidater er blitt foreslått i Tidsskriftets spalter. I Tidsskriftet nr. 11/1925 mente en innskriver å ha funnet et godt alternativ i en «liten fransk luftkjølet bil» (Tidsskr Nor Lægeforen 1925; 45: 597-8).

\section{Lagebil.}

Av Chr. Krohn, Moss.

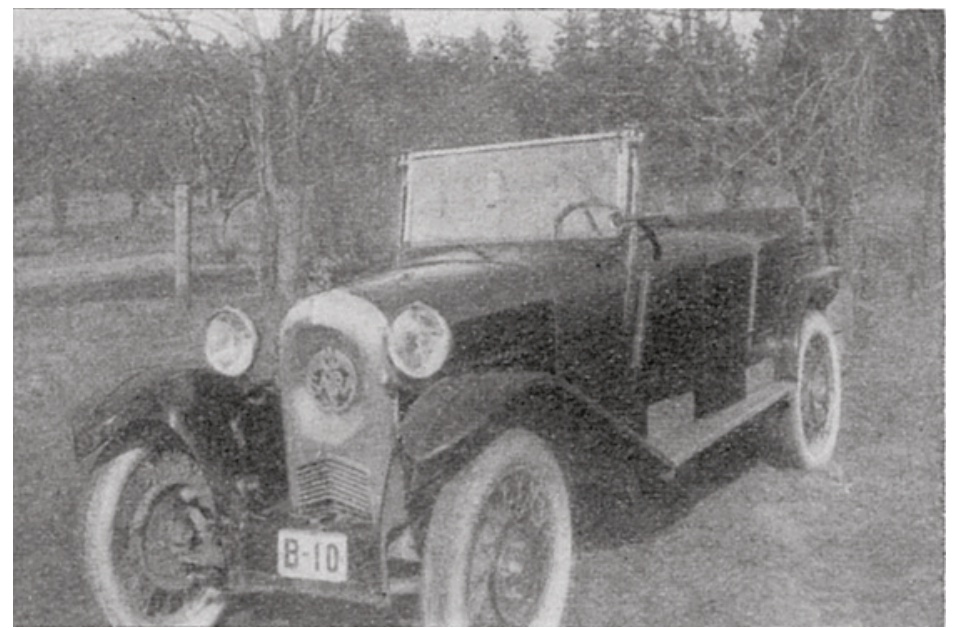

S. A. R. A.

Etpar ord om en liten fransk luftkjølet bil, som antages særlig at egne sig for lægebruk, tør kanske paaregne interesse. Kravene til en ideel lægebil er mange, hvorav nævnes: Den maa ikke være for stor, men let og bekvem i bruk, solid og stø. Let start fremfor alt. Billig i drift, helst ogsaa i indkjøp. Den ideelle lægebil bør være luftkjølet, hvorved radiator og varme blir overflødig. S. A. R. A. opfylder, saavidt jeg kan skjønne, de fleste av disse krav og er, saavidt mig bekjendt, den eneste 4-cylindrede luftkjølte bilen, som er at faa. Naar luftkjølesystemet - til hvis nærmere beskrivelse jeg ikke her skal opta plass - som hos «Sara» virker fuldt paalidelig, indebærer det for lægen, hvis bil altid skal være kjøreklar sent og tidlig, sommer og vinter, en ganske betydelig fordel. Det er vel et faatal av de bilende læger, særlig paa landet, som har opvarmet garage. Al bekymring for frysning $i$ radiator og vandkappe er ingen liten ulempe at bli kvitt. Personlig har jeg sat «Sara»s luftkjølesystem paa en god prøve under tæleløsningen ivaar, og denne paakjending klarte det helt tilfredsstillende.
Bilens øvrige egenskaper er kort fortalt følgende: Smal og lang (1,12 m. $\times 2,85$ m.). 4.cyl. motor, 8,28 hk., veiavgift kr. 20,90. Høisp. magnet, solex forgasser. Fuldt elektrisk utstyr (starter, lys og horn). Tverstillet forfjær, contrilever bakfjær. 4-hjuls bremser. 4 gir og revers, kuleskjaltning. Ingen differential. Solid chassis, stø gang $\mathrm{i}$ veien, god fjæring. Let at starte, ogsaa i kulden. Enkel og grei at stelle. Motoren har en forbausende trækevne til at være saa liten. Benzinforbruk 0,8 liter pr. $10 \mathrm{~km}$., oljeforbruk 2 liter pr. 800-1000 $\mathrm{km}$. Vognen er ikke egentlig billig i indkjøp, svarer omtrent til Fiat 501.

I nær fremtid faar fabrikken antagelig en forhandler i Oslo, saa spørsmaalet reservedeler ikke volder nogen vanskelighet. Indtil saa sker, maa vognen tages hjem direkte. Jeg staar gjerne til tjeneste med oplysninger for interesserte kolleger. 